\title{
FEMINIST ECOCRITICISM: THE NEW ECOFEMINIST SETTLEMENT
}

\author{
SERPIL OPPERMANN \\ Hacettepe University, Ankara
}

Recibido: 20/03/2013

Aceptado: 09/10/2013

\begin{abstract}
Taking into account the material feminist theories of "agency," "matter," and "body," this essay examines to what extent material feminisms and trans-corporeality can be productive models for conceptualizing feminist ecocriticism, an anti-phallogocentric ecocritical theory that analyzes the complex dynamics of material agencies across human and nonhuman bodies. By contesting gendered dualities and bodily boundaries, it opens up new ecocritical pathways to deconstruct the sexist, speciesist, and homophobic discourses of nature which served as a rhetorical strategy to associate female and queer human beings with animals/nature. Feminist ecocriticism is also a form of literary criticism that examines these issues in literary texts. Richard Powers novel Gain provides a palpable example as it highlights the permeability of bodily natures
\end{abstract}

Key-words: ecocriticism, feminist ecocriticism, ecofeminism, animals/ nature, Val Plumwood, Karen Warren, Greta Gaard, Richard Powers.

\section{Resumen}

Teniendo en cuenta las teorías del feminismo material sobre "agencia", "materia", y "cuerpo," este ensayo analiza hasta qué punto el feminismo material y la transcorporeidad pueden ser considerados como modelos productivos para conceptualizar la ecocrítica feminista, una teoría ecocrítica anti-falocéntrica que analiza la compleja dinámica de las agencias materiales a través de cuerpos humanos y no humanos. El hecho de cuestionar las dualidades de género y las fronteras corporales abre nuevos caminos ecocríticos para deconstruir los discursos sexistas, especistas y homófobos de la naturaleza que sirvieron como estrategia retórica para asociar a las mujeres y los homosexuales con seres animales/ naturaleza. La ecocrítica feminista es también una 
forma de crítica literaria que examina estas cuestiones a través de los textos literarios. La novela Gain de Richard Powers ofrece un ejemplo palpable que pone de relieve la permeabilidad de las naturalezas corporales.

Palabras clave: ecocrítica, ecocrítica feminista, ecofeminismo, animals/ naturaleza, Val Plumwood, Karen Warren, Greta Gaard, Richard Powers. 
Although ecocriticism has been slow to respond to the ethical and ideological questions raised by ecofeminism, which has in the first place subverted the masculinist matrix of ideological formations within Western cultures, the political, ethical, and the theoretical import of ecofeminist positions have recently been reconfigured within a new mode of ecocritical inquiry, called feminist ecocriticism. Instead of drawing a distinction between ecocriticism and ecofeminism, which would imply pitting one against the other, Simon Estok suggests that "building on the strengths of each approach, looking at ways they complement each other, and working toward defining more fully what each approach envisions," would be far more productive. This promise is inaugurated by Greta Gaard in her 2010 essay, "New Directions for Ecofeminism: Toward a More Feminist Ecocriticism," where she announces the emergence of feminist ecocriticism, and perceptively notes that:

the intersectional analysis of nature, gender, race, class, species, and sexuality is not confined to an essentialist definition of feminism or ecofeminism, but rather offers a strategic conceptual approach toward bringing about the social justice, economic and ecological democracy needed to solve environmental crises in the present moment. ${ }^{2}$

Following Gaard, I will argue that feminist ecocriticism brings a more pronounced feminist dimension to ecocritical studies, expanding ecocriticism's scope and critical trajectory toward environmental and women's reproductive justice, trans-corporeality of bodily natures, material feminisms, animal studies, and queer ecologies. Incorporating such diversity of perspectives in terms of gender, sexuality, race, identity, and species' rights, feminist ecocriticism affirms the necessity of a new theoretical feminist perspective in environmental literatures, cultures, and science studies. Feminist ecocriticism also adopts a posthumanist ethical stance which, as Stacy Alaimo contends, "allows us to forge ethical and political positions that can contend with numerous late

1. EstoK, Simon C., "Bridging the Great Divide: Ecocritical Theory and the Great Unwashed," ESC 31.4 (December 2005), pp.197-209. 199.

2. GAARD, Greta, "New Directions for Ecofeminism: Toward a More Feminist Ecocritcism," ISLE 17.4 (Autumn 2010), pp. 643-665. 659.

Feminismo/s 22, diciembre 2013, pp. 65-88 
twentieth/early twenty-first century realities in which 'human' and 'environment' can no longer be considered separate." ${ }^{3}$ From this perspective, feminist ecocriticism can be defined as the new ecofeminist settlement specifically in the fields of ecocritical studies and environmental humanities. Drawing selectively upon previous paradigms proposed within diverse branches of ecofeminist theory, ${ }^{4}$ which posited various "analyses of the connections among racism, sexism, classism, colonialism, speciesism, and the environment, ${ }^{15}$ feminist ecocriticism discloses an ecofeminist vision that includes a broader scope of embodied materialist analyses of posthumanist conceptions of corporeality, and their literary permutations in the intersections between ecofeminism and ecocriticism. Modeled upon Latour's concept of "the new settlement," "which he has proposed to contest the dualistic logic of modernity, I will frame my argument around the concept of a new ecofeminist settlement with a more reciprocally transformed sense of the human and nonhuman worlds. In a more specific sense, the new ecofeminist settlement can be read as an emergent configuration that debunks the objectification of the natural world, women, matter, bodily natures, and nonhuman species, and opens new eco-vistas into exploring the dynamic co-extensivity and permeability of human and nonhuman bodies and natures. Feminist ecoriticism is the paradigmatic form of this new approach that attempts to bring sustaining meanings in the realm of materiality, discourse, and cultural imaginary for the purpose of dismantling dualistic otherness framed by "the gendered and dualistic symbolism" 7 in Western thought. Like Timothy Morton's "ecology without nature," feminist ecocriticism offers a vision of ecology without gender. This is not to say that the human is reduced into a neutral category. On the contrary, the human (also the nonhuman) is a highly gendered and sexed category, but must be thought outside the confines of gendered dichotomies, and thus outside of their abductive power imbricated in heteronormative expectations, language, and what some theorists call heteropatriarchy. Feminist ecocriticism is, thus,

3. Alaimo, Stacy, "New Materialisms, Old Humanisms, or, Following the Submersible," NORA: Nordic Journal of Feminist and Gender Research. 19.4 (December 2011), pp.280284: 282.

4. Such as liberal feminism, cultural ecofeminism, social ecofeminism, socialist ecofeminism, vegetarian or animal ecofeminism.

5. GAARD, Greta, "Ecofeminism Revisited: Rejecting Essentialism and Re-Placing Species in a Material Feminist Environmentalism," Feminist Formations 23.2 (Summer 2011), pp. 26-53. 27.

6. See Latour, Bruno, Pandora's Hope: Essays on the Reality of Science Studies, Cambridge, Mass.: Harvard UP, 1999.

7. Plumwood, Val, Environmental Culture: The ecological crisis of reason, London: Routledge, 2002, p. 31. 
an anti-dualist, anti-phallogocentric theory, contesting anthropocentric and phallogocentric epistemologies, and subverting all gendered associations. It sheds light on the complex interconnections of gender, sexuality, ecology, and ideology that have impacts beyond women's bodies.

On that basis, it can be said that feminist ecocriticism proceeds from the perspective of a "posthumanist ethic of the respectful encounter with 'difference'/the Other." the differential constitution of humans and nonhumans. That is, differences and distinctions matter in the interconnections of human and nonhuman spheres, not in the sense of accepting the superiority of the human and the devaluation of the nonhuman or of privileging the nonhuman at the expense of the human, but in terms of their complex entanglements. In "Nature's Queer Performativity" Karen Barad lucidly explains why difference matters by stating that

the 'posthumanist' point is not to blur the boundaries between human and nonhuman, not to cross out all distinctions and differences, and not to simply invert humanism, but rather to understand the materializing effects of particular ways of drawing boundaries between "humans" and "nonhumans."

Barad's argument is premised upon the materializing practices of differentiating, and materializing effects of boundary-making practices. These practices produce "crucial materializing effects" that need to be accounted for without taking differences and distinctions between cultural and natural forces, and human and nonhuman actors, to be foundational. ${ }^{10}$

This vision that ostensibly highlights the concurrence of corporeal practice and production of social discourses, animates the new materialist theoretical discussions and standpoints of material feminisms that encourage us "to think transversally." In other words, the interactions between nature and culture, language and reality, between ecosystems and the social and cultural structures are so entangled that disregarding this fact leads us to more fragmentary thought which, as David Bohm would say, will bring more pollution,

8. See "The Posthumanities Hub," a platform at Tema Genus (Department of Gender Studies, Linköping University) for a critical framework of posthumanities and feminist networking: http://www.tema.liu.se/tema-g/Posthuman?l=en

9. BARAD, Karen, "Nature's Queer Performativity," Qui Parle 19.2 (Spring/Summer 2011), pp.121-158: 123-124.

10. Ibid., p. 124.

11. GuATTARI, Felix, The Three Ecologies, trans. Ian Pindar and Paul Sutton. London: Continuum, 2000, p.29

Feminismo/s 22, diciembre 2013, pp. 65-88 
disorder, and "destruction of the balance of nature."12 Thinking transversally, then, closes not only the Cartesian gap between mind and matter, but also allows us to recognize the ideological associations between speciesism and heterosexism, and intersecting issues of gender, sexuality, and the nonhuman world. Exemplifying this mode of liberatory thinking, Greta Gaard in her 2010 essay, "Strategies for a Cross-Cultural Ecofeminist Literary Criticism," concedes that such connections create "linked valuations" (such as associating masculinity with activity, rationality, and culture, and equating women and femaleness with nature and passivity) which in turn lead to a system of hierarchy. Consequently, Gaard observes, this kind of hierarchy is "used to justify the domination of women, nature, and all those so associated." ${ }^{13}$ Emphasizing the importance of "the centrality of social diversity and biodiversity as necessary foundations to our survival on this planet," ${ }^{14}$ she draws attention to the necessity of a deep critique of "the many forms of alienation, hierarchy, and domination (including but not limited to speciesism, sexism, racism, classism, heterosexism, ageism, ableism, and anthropocentrism). ${ }^{15} \mathrm{As}$ many ecofeminist thinkers have previously argued, the so-called naturalized forms of othering, speciesism, sexism, instrumentalism, and domination have entailed an almost exclusive emphasis on interconnected anthropocentric and androcentric assumptions concerning the intersections of sex and nature. Val Plumwood, for example, claims that dualisms, though not immediately seen as "variants of a gendered reason/nature contrast" 16 are derived from this basic link between sex and nature. In Ecofeminist Natures: Race, Gender, Feminist Theory and Political Action, Noël Sturgeon also deliberates over how nature is raced and gendered through such concomitant postulates. ${ }^{17}$ The political and ethical import of the relations between sexuality and nature has been widely discussed in a similar way and summed up by Karen Warren who has provided a theoretical space and conceptual framework for what she calls a

12. Bонм, David, Wholeness and the Implicate Order. 1980. London: Routledge rpt. 1980, 1995, p. 2.

13. GAARD, Greta, "Strategies for a Cross-Cultural Ecofeminist Literary Criticism," Ecozon@1.1(2010),pp.47-52.48

14. Ibid., p. 48

15. Ibid., p. 48.

16. PlumwOoD, Val, Feminism and the Mstery of Nature. Rpt. 1993. New York: Routledge, 1997, p. 45.

17. Sturgeon, Noël, Ecofeminist Natures: Race, Gender, Feminist Theory and Political Action, New York: Routledge, 1997, p.133. 
"transformative feminisms" in challenging anthropocentric and patriarchal systems of domination, including sexism, racism, speciesism, and naturism. ${ }^{18}$

It is imperative that feminist ecocriticism foreground more theoretically "the intersections of sex and nature" which, as Catriona Mortimer-Sandilands and Bruce Erickson note, "exist institutionally, discursively, scientifically, spatially, politically, poetically, and ethically." ${ }^{19}$ But it goes beyond mere theoretical foregrounding. It expands these intersections by theorizing the co-extensivity of and complex entanglements between bodies, natures, and discourses. The ideological implications of this move are such that our social and cultural meanings, and all political decisions, to quote Stacy Alaimo and Susan Hekman, "are scripted onto material bodies." ${ }^{20}$ Materiality is literally written onto the very flesh of our bodies, and our hazardous substances that are released daily in unimaginable quantities all around the planet are mapped onto all bodily natures leading, as Serenella Iovino points out, to significant "consequences of the entanglement of matter and meaning for ecocriticism." ${ }^{21}$ Understanding such interactions, or in Alaimo's conceptualization, "trans-corporeal" relations is, in Iovino's words, "essential to a process of emancipation and liberation." 22 Understanding that environmental toxins are feminist issues helps one understand and seek solutions for women's predicaments in different cultures, but also the interactions of sexuality and nature, of bodily natures, and of social and environmental forces and processes.

What is fundamental to feminist ecocriticism in this regard is to critically engage with the new materialist conceptualizations of matter (such as human and nonhuman bodies, and organic and inorganic substances and forces) as an active agency, and its biocultural constitutions. As Sandilands and Erickson put it, "sexual relations organize and influence both the material world of nature and our perceptions, experience and constitutions of that

18. WARREN, Karen, "Feminism and Ecology: Making Connections," Environmental Ethics 9.1 (1987), pp.13-20. 8-20.

19. SANDILANDS, Catriona-Mortimer and Bruce ERICKSON, "Introduction: A Genealogy of Queer Ecologies," in Queer Ecologies: Sex, Nature, Politics, Desire, eds. Catrinoa Mortimer-Sandilands and Bruce Erickson, Bloomington: Indiana University Press, 2010, p. 5.

20. Alaimo, Stacy and Susan HeKman, "Introduction: Emerging Models of Materiality in Feminist Theory," in Material Feminisms, eds. Stacy Alaimo and Susan Hekman. Bloomington: Indiana University Press, 2008, pp.1-19: 8.

21. IOVINO, Serenella, "Steps to a Material Ecocriticism: The Recent Literature about the 'New Materialisms' and Its Implications for Ecocriticial Theory," Ecozon@ 3.1 (2012), pp.134-145:136.

22. Ibid., p. 135.

Feminismo/s 22, diciembre 2013, pp. 65-88 
world." ${ }^{23}$ Many new materialist feminists endorse this emerging paradigm with interesting accounts of how sexual diversity, sexual relations in both the human and the nonhuman world, and material agency transform our biocultural formations and our still persistent anthropocentric conceptions of nature, culture, sex, gender, and matter. Stacy Alaimo and Susan Hekman's Material Feminisms (2008) is perhaps one of the most critically acclaimed collection that heralds the "transgressive, progressive potential for theoretical engagement with materiality." ${ }^{24}$ Material feminisms could be useful in developing feminist ecocritical models that are more inclusive of social, sexual, and biodiversity and provide guidance in a world of increasingly detrimental and acute ecological crisis where, as Val Plumwood has incisively argued, "human-centered conceptual frameworks are a direct hazard to non-humans, but are also an indirect prudential hazard to Self, to humans, especially in a situation where we press limits." ${ }^{25}$ This awareness has resulted in the new materialist rethinking of bodies and natures, which can be the driving force behind feminist ecocriticism's aim of building the new ecofeminist settlement.

The new materialists (and material feminists) perceive nature as "an active, signifying force; an agent in its own terms; a realm of multiple, inter- and intra-active cultures." ${ }^{26}$ Being thus liberated from its previous conceptualizations as a "blank, silent resource for the exploits of culture," and from being considered as a "repository of sexism, racism, and homophobia," ${ }^{27}$ nature is discussed as a significant participatory force field in the entanglement of meaning and matter. The very materiality of nature's bodies, forces, and substances is deliberated over their interconnections with discursive formations in social, cultural, political, literary, and philosophical fields. The intersections of materiality and discursivity create agentic fields of mutual emergence of all life forms, and connect human knowledge practices with biosemiotic emergences, where "culture is emergent in nature, and mind is emergent in body/ environment." 28 To elucidate this point, and the co-emergence of natural and

23. SANDILANDS, Catriona-Mortimer and Bruce ERICKSON, "Introduction." p.5.

24. See note 9 in Stacy Alaimo's chapter "Eluding Capture: The Science, Culture, and Pleasure of 'Queer Animals," in Queer Ecologies, p.69.

25. Plumwood, Val, "Nature in the Active Voice," Australian Humanities Review 46 (May 2009), pp.113-129:117.

26. Alaimo, Stacy and Susan Hekman, "Introduction: Emerging Models of Materiality in Feminist Theory," p.12.

27. Ibid.

28. WhEELER, Wendy, "The Biosemiotic Turn: Abduction, or the Nature of Creative Reason in Nature and Culture," in Ecocritical Theory: New European Approaches, eds. Axel GoOdBody and Kate RigBy, Charlottesville: University of Virginia Press, 2011, pp. 270282: 271. 
cultural evolution, Wendy Wheeler writes in her Introduction to Biosemiotics: Nature-Culture-Science-Semiosis, one of the "Living Books About Life," that

questions raised by biosemiotically informed understandings concern not only the ways in which cultures rearticulate patterns in nature within their own historical cultural Umwelten, and the understanding of 'mind' as embodied and enworlded distributed intelligence, but also the relationship between living and nonliving nature. That the material world is legible both cenoscopically (for everyone) and idioscopically (via science) raises the topic of physiosemiosis - the fact that, for living things, matter is lively and potentially legible in living body-mind-Umwelten. Peirce himself thought that matter was 'effete mind' (Peirce, 1992: 293) in a 'universe [...] perfused with signs' (Peirce, 1998b: 394). ${ }^{29}$

The biosemiotic attestation that matter is agentic, lively, and perfused with signs, and that the material world is legible, recalls not only Jane Bennett's theorization of matter's vibrancy and vitality, but also Karen Barad's conceptualization of the complementarity between matter and discourse, and matter and meaning. Thus, from a perspective that conflates materiality and discursivity, and a vision that cultivates the co-emergence of "naturecultures," 30 the new materialist stance creates an interesting critical impulse toward an epistemic shift in social sciences, environmental humanities and feminist theory. This radical vision is foremost premised upon the critically acknowledged agentic capacity of "vibrant matter." Theorizing "a vitality intrinsic to materiality," and identifying the "human-nonhuman assemblages as a locus of agency,"31 Jane Bennett, for example, proposes a shift from "environmentalism to vital materialism, from a world of nature versus culture to a heterogeneous monism of vibrant bodies." ${ }^{32}$ This conceptual shift is articulated in such metaphorical terms as Andrew Pickering's concept of the mangle, the "constitutive intertwining ... between material and human agency;"33 Bruno Latour's actor-network theory, a network in which both human and nonhuman actors are semiotically and materially interrelated; Stacy Alaimo's "trans-corporeality;" and Deleuze and Guattari's "assemblages." Taking her cue from the concept of

29. WHEELER, Wendy, "Introduction," Biosemiotics: Nature-Culture-Science-Semiosis, Living Books About Life, Open Humanities Press, JISC, 2011, n.p. http://www.livingbooksaboutlife.org/books

30. 'Naturecultures' is Donna HARAWAY's conceptualization of the integrative vision of nature and culture.

31. BennetT, Jane, Vibrant Matter: A political ecology of things, Durham: Duke University Press, 2010, pp. xiii, 37.

32. Ibid., p.121.

33. Pickering, Andrew, The Mangle of Practice: Time, Agency, \& Science, Chicago: University of Chicago Press, 1995,p.15.

Feminismo/s 22, diciembre 2013, pp. 65-88 
assemblage to indicate how the human is always already intertwined with the nonhuman, Bennett invokes "bacteria colonies in human elbows," and thus shows "how human subjects are themselves nonhuman, alien, outside, vital materiality." ${ }^{34}$ According to Bennett, the "human agency is always an assemblage of microbes, animals, plants, metals, chemicals, word-sounds, and the like-indeed, that insofar as anything "acts" at all, it has already entered an agentic assemblage." 35 The interchanges of "humans and their (social, legal, linguistic) constructions," and "active and powerful nonhumans: electrons, trees, wind, fire, electromagnetic fields" 36 are theorized in a horizontal way. Donna Haraway refers to such mingling of diverse entities both human and nonhuman as "the partners in infoldings of the flesh." Similar to Bennet's view of entanglements, Haraway considers all material "things" to be "composed of diverse agents of interpretation," and conceives them as "conjoined forces." 37 The way she elaborates on this conjunction foregrounds a possibility not of coherent and harmonious blend of human and nonhuman natures, but one that blatantly exposes the problematic "motley of associations" (such as enclosure) and their effects in the compounds:

Never purely themselves, things are compound; they are made up of combinations of other things coordinated to magnify power, to make something happen, to engage the world, to risk fleshly acts of interpretation.

Technologies are always compound. They are composed of diverse agents of interpretation, agents of recording, and agents for directing and multiplying relational action. These agents can be human beings or parts of human beings, other organisms in part or whole, machines of many kinds, or other sorts of entrained things made to work in the technological compound of conjoined forces. Remember also, one of the meanings of compound is "an enclosure, within which there is a residence or a factory"-or, perhaps, a prison or temple. Finally, a compound animal in zoological terminology refers to a composite of individual organisms, an enclosure of zoons, a company of critters infolded into one. Connected by Crittercam's stolon-that is, the circulatory apparatus of its compounded visualizing practices—zoons are technologies, and technologies are zoons. ${ }^{38}$

In their introduction, Diana Coole and Samantha Frost, the editors of the much acclaimed volume, New Materialisms: Ontology, Agency, and Politics also discern matter as "active, self-creative, productive, unpredictable," with

34. Ibid., p.120.

35. Ibid., pp. 120-121.

36. Ibid., p. 24.

37. Haraway, Donna, J. When Species Meet, Minneapolis: University of Minnesota Press, 2008, p. 250

38. Ibid., p. 250.

Feminismo/s 22, diciembre 2013, pp. 65-88 
"emergent, generative powers," which can only be properly understood in what they call" "choreographies of becoming." ${ }^{39}$ The diva of the new materialist theory, quantum physicist Karen Barad, however, provides the most elaborate theoretical framework for this new paradigm by proposing a "posthumanist performative approach to understanding technoscientific and other naturalcultural practices that specifically acknowledges and takes account of matter's dynamism." ${ }^{40}$ This dynamism, she argues, is agency. "Agency is not an attribute but the ongoing reconfigurings of the world. The universe is agential intra-activity in its becoming." ${ }^{41}$ Barad coins the term "intra-action" to explain "the mutual constitution of entangled agencies." ${ }^{\text {" Intra-action does }}$ not assume separate agencies that precede their interaction. Rather distinct agencies, Barad claims, emerge through their intra-action. Barad's posthumanist approach, as I have argued elsewhere, has significant implications for feminist ecocriticism, because it provides

a solid foundation for feminist discussions of the body that transcends the dualism of discourse and matter, as well as biological sex and gender as categories of cultural analysis. The gendered bodies are no longer disembodied discursive subjects, but emerge through their differential becoming as embodied subjects intra-acting with myriads of visible and invisible agents of the material world (bacteria, viruses, toxic chemicals, food, water, energy)." ${ }^{43}$

In a categorical compliance with the insights of the new materialisms, feminist ecocriticism's conceptual horizons rest on the assumption that the gendered dichotomies hidden in the phallogocentric Western thought can be surmounted by adopting a relational ontology emerging from what Karen Barad calls "material-discursive practices." According to Barad, the "relationship between the material and the discursive is one of mutual entailment." 44 Accommodating this integral vision, feminist ecocriticism considers gendered bodies, not as purely cultural or discursive constructs, but as differentially constituted material-discursive subjects, enmeshed in the material world of powerful volatile agents, such as toxic chemicals, radioactivity, and viruses.

39. Coole, Diana and Samantha Frost, "Introducing the New Materialisms," in New Materialisms: Ontology, Agency, and Politics, eds. Diana Coole and Samantha Frost. Durham: Duke University Press, 2010, pp. 1-43: 9-10.

40. BARAD, Karen, Meeting the Universe Halfway: quantum physics and the entanglement of matter and meaning, Durham, Duke University Press, 2007, p.135.

41. Ibid., 141.

42. Ibid., p.33.

43. See OpPermann, Serpil, "Feminist Ecocriticism: A Posthumanist Direction in Ecocritical Trajectory," in International Perspectives in Feminist Ecocriticism,eds. Greta GAARD, Simon C. Estok, and Serpil Oppermann, New York: Routledge, 2013, pp. 19-36: p.25. 44. BARAD, Karen, Meeting the Universe Halfway, p. 152

Feminismo/s 22, diciembre 2013, pp. 65-88 
It investigates the embodiment of gendered bodies in earthly processes, and how our bodies interact with myriad forms of agentic matter and especially poisonous substances. These are agentic lethal entities Stacy Alaimo labels as "deviant agencies of xenobiotic chemicals," 45 which co-constitute much of bodily natures in highly toxic environments both humans and nonhumans inhabit today. The human body, Alaimo writes, "is permeable and thus vulnerable to particular locations and substances," and "the very substance of the self is interconnected with vast biological, economic, and industrial systems that can never be entirely mapped and understood." ${ }^{46}$ In this sense, the social and the biological compose what Nancy Tuana calls "viscous porosity" of human and nonhuman realms just as "the porosity of entities" 47 does in her understanding of the interchanges between human and nonhuman bodily natures. Tuana discusses hurricane Katrina as "emblematic of the viscous porosity between humans and our environment, between social practices and natural phenomena." ${ }^{8}$ Viscous porosity explains the interweaving of human agency with the more-than-human world in ways that illuminate how we are co-constituted; how, for example, the water we drink, the food we consume, and the mite we sleep with in our beds become part of our flesh, making all ontological divides between the human and the environment untenable. Trans-corporeality is another significant new materialist concept that explains the inseparability of human corporeality from nonhuman environments. By emphasizing the movement across bodies, trans-corporeality "reveals the interchanges and interconnections between various bodily natures." ${ }^{49}$ In her important essay "Trans-Corporeal Feminism and the Ethical Space of Nature," Stacy Alaimo defines the concept as a theoretical site, "a place where corporeal theories and environmental theories meet and mingle in productive ways." ${ }^{50}$ Like viscous porosity, trans-corporeality designates ethical, social, biological, and cultural meanings that emerge from what Alaimo calls the "literal contact zone between human corporeality and more-than-human nature." ${ }^{51}$

45. Alaimo, Stacy, Bodily Natures: Science, Environment, and the Material Self, Bloomington, Indiana University Press, 2010, p 139.

46. Ibid., p.23.

47. TuAnA, Nancy, "Viscous Porosity: Witnessing Katrina," in Material Feminisms, eds. Stacy Alaimo and Susan Hekman. Bloomington, Indiana University Press, 2008, pp. 188-213.191.

48. Ibid., p. 193.

49. Alaimo, Satcy, Bodily Natures, p.2.

50. Alaimmo, Stacy, "Trans-Corporeal Feminism and the Ethical Space of Nature," in Material Feminisms, eds. Stacy Alaimo and Susan Hekman. Bloomington, Indiana University Press, 2008, pp.237-264. 238.

51. Ibid., p. 238. 
Being corporeally enmeshed with heterogeneous agencies that comprise the bodily natures of often unpredictable "nonhuman creatures, ecological systems, chemical agents, and other actors," ${ }^{2}$ brings multiple risks in the form of incurable illnesses and viral diseases such as metastatic cancer, birth defects, mad cow disease, or avian influenza endemic to birds, known as the deadly chicken flu, as well as contamination of landscapes and waterscapes, extinction of species, biodiversity loss, and climate change. Trans-corporeality also discloses the political and cultural dimensions of toxic human and animal bodies. Environmental historian Nancy Langston highlights this dimension in Toxic Bodies: Hormone Disruptors and the Legacy of DES, and makes a clarion call for a new ecology of health. She calls the bodies of American women toxic waste sites, who are exposed to synthetic chemicals, such as the hormone disruptor diethylstilbestrol (DES) prescribed by doctors to women initially for menopause and used by American farmers on cattle to promote rapid weight gain. Although DES is no longer used, "livestock continue to be treated with steroids," Langston contends, "while pesticides continue to proliferate in the food supply." She also points to the dangers of plastics such as bisphenol A, which seep into drinking water, and "every month brings new reports of intersex fish and cancer-ridden whales." ${ }^{13}$ Langston's compelling argument reveals how such synthetic chemicals poison the bodies of livestock, human and wildlife bodies, and disrupt the ecosystems. DES is a palpable example of trans-corporeality, with disturbing political and economic reverberations. As Langston elaborates: "Toxic chemicals have the potential to cross the boundaries between species and generations, altering the hormone systems that shape our internal ecosystems of health, as well as our relationship with the broader ecosystems around us." ${ }^{44}$ In a feminist ecocritical context, women's bodies as the very material sites perlocated through dangerous nonhuman material agencies, are also complex sites of ideological, ecological, and discursive power relations whereby we are encouraged to rethink the materiality of bodies interconnected with their discursive formations.

Toxic Bodies can be read as a profound contestation of women's bodies as a matrix for phallogocentric imaginary. Evidently, toxic bodies signify a denaturalization of the logic of patriarchal categories, which relegate the female body (along with queer bodies human and nonhuman) to radical alterity. Trans-corporeality in this regard enables us to envision bodies, both

52. Ibid., p. 238.

53. LANGSTON, Nancy, Toxic Bodies: Hormone Disruptors and the Legacy of DES, New Haven: Yale University Press, 2010, pp. xi-xii.

54. Ibid., p. 2.

Feminismo/s 22, diciembre 2013, pp. 65-88 
human and nonhuman, as "empirical actors" or "significant players" not only in "games of power" 55 as Diana Coole and Samantha Frost claim, but also in bioethical, biopolitical and biotechnological practices, policies, regulations, and their theoretical imbrications.

The complex dynamics of interdependent material agencies across human and nonhuman bodies animates much of the discussion in material feminisms, a discussion that has centered on the epistemological reconfigurations of the material-discursive landscapes and bodies, often infused with unpredictable agentic forces. How can we express these phenomena in ways that would rescind polarized logic? Or, as Val Plumwood asks in "Journey to the Heart of Stone": "How can we re-present experience in ways that honour the agency and creativity of the more-than-human world?" 56 Writing about the stone as an active and responsive partner in daily experience, Plumwood's answer is to be radically open to the Other ${ }^{57}$-in this case the stone as the alleged dead matter-so that we can really recognize "the speaking and acting stone that is all around us." ${ }^{15}$ If we can acknowledge the narrative voices of the stone, we can more easily deconstruct the sexist, speciesist, and homophobic discourses of nature (such as animality), which served as a rhetorical strategy to associate female and queer human beings with animals/nature. This approach basically challenges the exceptionalism that has been attributed to human agency (always male), and subverts "the conventional sense that agents are exclusively human who possess the cognitive abilities, intentionality, and freedom to make autonomous decisions." 59 This conceptual expansion of agentic boundaries opens new feminist pathways to build anti-phallogocentric discourses, because the new materialist concept of agency signifies liberation from objectification process whereby nature and materiality (and everything associated with these categories, including women, animals, minerals, etc.) get reduced to being mere objects of knowledge and exploitation.

The conceptualization of agency in terms of creativity, generative power, action, and effectivity, rather than in terms of its human attributes of intentionality, purposive behavior, rationality, and moral will, opens up an understanding of freedom consonant with feminist ecocriticism's vision in

55. CoOlE, Diana and Samantha Frost, "Introducing the New Materialisms," pp.19-20.

56. Plumwood, Val, "Journey to the Heart of Stone," Culture, Creativity and Environment: New Environmentalist Criticism, eds. Fiona Becket and Terry Gifford. Amsterdam: Rodopi, 2007, pp.17-36: 19.

57. Ibid., p.22.

58. Ibid., p. 34

59. COOLE, Diana and Samantha FROST, "Introducing the New Materialisms." p.10. 
that, to quote Elizabeth Grosz, freedom is "always and only enacted within and through the materiality that life and the nonliving share." ${ }^{60}$ Elucidating Bergson's concept of freedom, that she claims coheres readily with feminist conceptions of liberation, sexual justice, the right to self-making, and struggle for autonomy, Grosz maintains that freedom is primarily to be understood as a capacity of the body. "It is linked to the body's capacity for movement, and thus its multiple possibilities for action." Freedom, according to Grosz, "is attained only through the struggle with matter, the struggle of bodies to become more than they are, a struggle that occurs not only on the level of the individual but also of the species." ${ }^{11}$ Since freedom functions through activity Grosz observes, gayness, for example, becomes "the enactment of freedom that can refuse to constrain sexuality and sexual partners to any given function, purpose, or activity." ${ }^{62}$ A more striking example of how freedom functions through activity can be given from more than 1500 animal species with sexual diversity, or homosexuality, which can "transform our conceptions of nature, culture, sex, gender, and other fundamental categories." ${ }^{33}$ Queer animals' same-sex behavior is documented in such publications as Bruce Bagemihl's Biological Exuberance: Animal Homosexuality and Natural Diversity (1999), Volker Sommer and Paul L.Vasey's edited volume, Homosexual Behaviour in Animals: An Evolutionary Perspective (2006), and Aldo Poiani's Animal Homosexuality: A Biological Perspective (2010), which point to the performative enactment of freedom from an evolutionary perspective. A performative understanding of this behavioral pattern seen in "hundreds of mammals, birds, reptiles, amphibians, fishes, insects, spiders and other invertebrates" ${ }^{64}$ clearly contests the persistent heteronormative perception of natural agencies that are believed to lack autonomy. The same-sex behavior in numerous animal species illustrates the posthumanist performativity of material bodies in their intra-active becoming.

60. Grosz, Elizabeth, "Feminism, Materialism, and Freedom," in New Materialisms: Ontology, Agency, and Politics, eds. Diana Coole and Samantha Frost, Durham: Duke University Press, 2010, pp. 139-157: 142.

61. Ibid., p.152.

62. Ibid., 153.

63. Alaimo, Stacy, "Eluding Capture: The Science, Culture, and Pleasure of 'Queer' Animals," in Queer Ecologies: Sex, Nature, Politcs, Desire, eds. Catriona MorTIMER-SAndILANDS and Bruce ERICSON, Bloomington: Indiana University Press, 2010, pp. 51-72: 59.

64. SOMMER, Volker and Paul L.VASEY, "Introduction. Homosexual behavior in animals: topics, hypotheses and research trajectories," in Homosexual Behaviour in Animals: An Evolutionary Perspective, eds. SOMMER, Volker and Paul L.VASEY, Cambridge: Cambridge University Press, 2006, pp. 3-44. 5.

Feminismo/s 22, diciembre 2013, pp. 65-88 
Employing this renewed sense of freedom, feminist ecocriticism recasts the ethical concerns about the experience of queer animals and trans-gendering in more-than-human environments to make a central place for posthuman ethical values. This particular feminist focus on queer elements in nonhuman nature, for example, not only provides "better accounts of the sexual diversity of natural creatures" ${ }^{15}$ as Stacy Alaimo deftly notes, but also provokes a rethinking of "our most basic sense of what nature and culture mean." ${ }^{\prime 66}$ The enactment of freedom is closely associated with agency, which Barad consolidates as "'doing' or 'being' in its intra-activity." ${ }^{77}$ That means, the acts of nature are emblematic of nature's intra-activity, its queer performativity. It is through such dynamics that the interplay of agential bodies and the environment constitutes "the ongoing materialization of the world in its intra-active becoming. ${ }^{168}$ Intersex animals instantiate one of the many dimensions of this ongoing process.

This compelling reconceptualization of bodily natures in action, especially the emphasis on the interchanges between human or nonhuman corporeality and the environment, and the theorizing of the permeable boundaries between the human and the nonhuman clearly indicates the infallible trans-corporeal proximity of intermingled bodies and horizons, consonant with feminist ecocriticism's objective of eliminating naturism, sexism, speciesism, and homophobia as dualistic othering processes. Charting the intersections of human bodies, environmental risks, toxic landscapes, health, and cultural practices within this new ecofeminist settlement, feminist ecocriticism encourages new knowledge practices that would "foster ecology of literary knowledge ... not stigmatized by gendered natures." ${ }^{169}$ Being attentive to social, political, and cultural matters, and effectivity of matter in its various forms and processes, feminist ecocriticism aims at producing a more capacious sexual and environmental understanding, and at paving the way to new ecocritical interpretations of literary and cultural narratives that are more encompassing of intersections of sexuality and nature, bodies and the environment, and their materializing effects. To put it briefly, feminist ecocriticism suggests an emancipatory stance that proceeds in a dialectical relation to practice. Exploring literary and cultural texts where female corporeality and nonhuman bodies are problematized, contested and disrupted, feminist ecocriticism discloses

65. Alaimo, Stacy, "Eluding Capture," p.54.

66. Ibid., p. 55.

67. BARAD, Karen, Meeting the Universe Halfway, p.178.

68. Ibid., p. 180.

69. Oppermann, Serpil. "Feminist Ecocriticism: A Posthumanist Direction," p. 31. 
how literature intersects with life itself. The body, here, as the site of theoretical considerations, and as a cultured gendered subject intra-acting with other bodies (animals, plants, chemicals, food, bacteria, etc.) as material agents suggests the possibility of a politics and poetics of nature through a broader perception of reality that includes ethics, genetics, chemistry, politics, and biotechnological advances. Furthermore, exploring "the challenging of the human/machine (nature/culture) boundary" in contemporary literary imagination, "both theoretically and practically with advances in biotechnology," or "discourses defining the "posthuman' condition"70 as Laura Bartlett and Thomas B. Byers put it, has significant implications in the critical challenge of patriarchal ideologies, suspicious biotechnological developments, and medical practices.

To exemplify such a feminist ecocritical analysis, Richard Powers's novel Gain can be taken as a palpable literary instance. Gain presents the intertwined stories of an international conglomerate, Clare, that starts out in the $19^{\text {th }}$ century as a soap company in Boston and grows into a mega-corporation in the $20^{\text {th }}$ century, and of an estate agent in Lacewood, Illinois, Laura Bodey, whose body is taken over by ovarian cancer just as her town is polluted by the toxic waste released by its Clare factory that produces soap, fertilizers, pesticides, bleaches, agricultural chemicals, floor wax, pharmaceuticals, artificial cheese, and house siding. Clare is built by the efforts of three brothers, Samuel, Resolve, and Benjamin, who follow in the footsteps of their father Jephthah Clare's shipping business in the early Republic protectionist tariffs. Becoming successful soap and candle manufacturers, the brothers carry Clare from household production to mass production, and developing a new conception of cleanliness, they cleverly necessitate the consumption of soap: "The mass hygiene movement also turned out in force, ready to convert soap from an incidental indulgence to a cornerstone of rectified living." ${ }^{71}$ During its speedy growth throughout the $19^{\text {th }}$ and early $20^{\text {th }}$ centuries the company uses its invention of packaging and product name recognition, with a trademark stamp of an Indian Brave on its Native Balm soap, "the perfect cure for the country's growing ablutomania, a cleanliness craze Clare had helped to cause." 72 The standardization of production, enforced by international competition, however, results in an impersonalization process and the unionization efforts of its workers. Clare also implements technological advances when

70. BARTLETt, Laura and Thomas B. Byers, "Back to the Future: The Humanist Matrix," Cultural Critique 53, Posthumanism (Winter, 2003),pp. 28-46: 29.

71. POWERS, Richard, Gain, New York: Picador, 1998, p.222.

72. Ibid., p. 197.

Feminismo/s 22, diciembre 2013, pp. 65-88 
Benjamin develops a laboratory that helps expand Clare from simple soap to diverse chemical production. The Clare laboratory turns "soda and animal waste to balm. Sulfur and soda to bright bleaches and colors. Gaslight waste to fertilizer. Medicaments from bicarbonate and lime.... All things chemical came from some other chemical thing. Man might learn to become matter's investment banker." ${ }^{73}$ This historical narrative that dominates the first half of the novel is intertwined with Laura's present-day story when the company is producing "super-pesticides." 74

Laura's cancer and Clare become more closely correlated in the second part of the narrative which progressively underlines the environmental consequences of Clare's work on chemical change, of properties of fat transmogrified to soap, for example, and the change of Laura's cells to cancerous ones. The transformation of matter is mapped onto Laura's body as well as onto the town's environment, its soil and water. In the second half of the book, Laura's story dramatically overtakes that of Clare, revealing the bodily effects of the medical industry, the appalling effects of chemotherapy, which ravages around Laura's body and mind, as well as her environment. Like other houses in Lacewood, Laura's house is full of Clare products that are present as invisible ecological contaminants. "Floor by Germ-Guard. Windows by Clare-Thru. Table by Colonial-Cote." As Laura shockingly recognizes, "Clare hiding under the sink, swarming her medicine chest, lining the shelves in the basement, parked out in the garage, piled up in the shed." ${ }^{75}$ It is suggested in the narrative that these contaminants may have accumulated over time in Laura's body tissues finally resulting in ovarian cancer. Laura also realizes that this is a kind of epidemic she had failed to see before:

Not just that packed cancer room at the hospital, the ring of bodies circled around their IV's, a new batch each time she visits. Not just the neighbor's sister-in law's father. It is everywhere. She cannot turn around without running into someone else. Everybody is battling cancer. Why did she never see these people before? ${ }^{76}$

Depicting her everyday routine of gardening, showing houses to her clients, taking care of her children Ellen and Tim, and dealing with her ex-husband Don, and her lover Ken, Laura's story gradually focuses on the materializing effects of her ovarian cancer and thus the deterioration of her body. Laura is tested for and diagnosed with cancer upon a routine medical exam, which,

73. Ibid., p.203

74. Ibid., p.293.

75. Ibid., p. 345.

76. Ibid., p. 242. 
the novel hints, is caused by environmental pollution from Clare. During the course of her progressive sickening, Laura realizes that nothing is safe:

We are all surrounded. Cucumber and squash and baked potato. Fish, that great health food she's been stiffing down the kids for years. Garden sprays. Cooking oils. Cat litter. Dandruff shampoo. Art supplies. Varnish. Deodorant. Moisturizers. Concealers. Water. Air. The whole planet, a superfund site. Life causes cancer. ${ }^{77}$

Indeed, as the company deals with such substances ranging from nitrogen tetroxide, polyethylene plastic, to "aluminum sulfate, aluminum silicate, titanium dioxide, hydrated silica, hydrated alumina, tale, barium sulfate $[\ldots]$ polyacrylamide resins [...] and asbestos" 78 among many others, their environmental effects become inevitable. The powerful agency of these substances beyond human control becomes manifest in Laura's tragic descent into death. The material entanglements between Laura's body and Clare entail that the relationship between bodies and the pervasive presence of xenobiotics is much more intimate than accidental exposure to toxins around. Laura's toxic body in its deterioration becomes indistinguishable from the equally deteriorating surrounding landscape polluted by Clare's chemical products. Therefore, environmental illness and bodily disease conflate in their permeable boundaries blurring the line between inside and outside, biological and social.

In general, the novel implicitly suggests that the body is reconfigured through an intra-active engagement with toxic nonhuman forces produced through technoscientific, medical, and biotechnological practices. The materialization of toxic bodies, then, is depicted in a field of material agency, which cannot be captured or eliminated by any means. As the novel expatiates on it in painstaking detail, the idea that we can control the uncontrollable has, in ecological contexts, to borrow Katherine Hayles's words, "proven to be a tragic illusion." 79

In this current situation that the novel depicts with accurate detail, human and material agency are reciprocally entangled to form agentic assemblages in "toxic, trans-corporeal, material places." The material effects of such corporeal interchanges are not only manifest in diseases like cancer, but also in anthropogenic changes in the more-than-human world, like climate

77. Ibid., p.323.

78. Ibid., p. 393.

79. PiPeR, Arthur. "How We Became Posthuman: Ten Years On: An Interview with N. Katherine Hayles," Paragraph 33.3 (2010), pp. 318-330: 325.

80. Alaimo, Stacy, "Trans-Corporeal Feminisms and the Ethical Space of Nature," p. 261.

Feminismo/s 22, diciembre 2013, pp. 65-88 
disturbances (extreme weather conditions are also highlighted in the novel) as well as in power relations. Laura's example shows how the female body is infiltrated and thus disrupted by hazardous material agency and how it becomes a symbolic site of political contestation and power struggle between the law firm that files a lawsuit against Clare and the company's fight against the resulting decline in its shares. Recounting how the body is enmeshed, not only materially but also socially and politically in the risky world of material agencies in socio-material, historical, and ecological contexts, Gain conveys the idea that corporeality is always imbricated in "networks that are simultaneously economic, political, cultural, scientific, and substantial." 81

What makes this novel especially compelling for feminist ecocriticism is its ambivalent stance on the effect of corporate bodies, like Clare, on female bodies that are entangled with lethal substances, and their social, ecological, economic, ideological, and gendered dimensions. The tragic descent of Laura's body framed within the industrial ascent of Clare's history provoke ethical dilemmas, such as the question of how to deal with chemicals used in production of soaps, cosmetics, detergents, food, bleaches, fertilizers, pharmaceuticals and similar materials that perfuse our daily lives, providing material comforts while endangering our lives, and in a fundamental sense, defining our mundane experiences. As such, Gain represents the materialization effects of capitalist production and consumption through modern corporate production, which becomes a correlative to Laura's cancer, and also causes environmental devastation. To put it another way, while Clare grows through controlling natural resources, Laura's cancer grows through uncontrollable forces that result from tampering with nature's processes. This is the central motif of the novel, the mangle of material gain and cancer in a world of deviant material agency.

From the feminist ecocritical perspective cancer is a concrete invocation of toxic material agencies. It emerges from a reality in which chemical agents seem to "dictate where and how they find sustenance..." ${ }^{12}$ Confronting such "pressing bioethical and biopolitical questions" ${ }^{13}$ as those ambiguously raised in Gain, feminist ecocriticism investigates the dynamics of bodies and environments in their material-discursive, textual, and cultural forms. Reading literary texts in this specific way, and interpreting posthuman ecological environments, bodies, and texts using the conceptual models of the new materialisms, feminist ecocriticism creates a vision of interrelated forces that

81. Alaimo, Stacy, Bodily Natures, p. 20.

82. CoOle Diana and Samantha Frost, "Introduction," p. 19.

83. Ibid.,p. 21. 
shape contemporary life, knowledge practices and discourses, and insists on new ethical considerations, standpoints, and transformative moral vistas. It takes the emerging "posthuman players" to quote Iovino, in their "alien materiality that interferes and co-acts with the bodies of living organisms and living land, exposing - by way of its dynamics of material permeability and trans-corporeality - the social and ethical blind spots of social constructs and political practices." ${ }^{84}$ The emerging posthuman understanding of the agency of such players prompts a theoretical space for a new settlement that can account for the ways in which the human is imbricated in medical, technical and economic networks. This is what feminist ecocriticism endorses in its commitment to change our "thinking about the relationship of culture and society to the natural world." ${ }^{85}$ What it brings as a new dimension is the posthumanist accounts of these relations. In this regard, the contemporary posthumanist logic of human-nonhuman relations is also the logic of feminist ecocritical studies where difference and otherness are indexed on a non-hierarchical ideology, and where otherness is not "defined on a hierarchical scale of pejorative differences." 86 Otherness instead marks "the sexualized bodies of women; the radicalized bodies of ethnic or native others and the naturalised bodies of animals and earth others." ${ }^{87}$ Posthumanism in this sense is, as Rosi Braidotti claims, "a fast-growing new intersectional feminist alliance. It gathers the remains of post-structuralist anti-humanism and joins them with feminist re-appraisals of contemporary genetics and molecular biology in a non- deterministic frame." 88 And feminist ecocriticism is its new ecofeminist settlement.

\section{Bibliographic References}

ALAimo, Stacy. "Trans-Corporeal Feminism and the Ethical Space of Nature." In Material Feminisms, eds. Stacy Alaimo and Susan Hekman. Bloomington, Indiana University Press. 2008. Pp. 237-264.

84. IOvinO, Serenella, "Toxic Epiphanies: Dioxin, Power, and Gendered Bodies in Laura CONTI's Narratives," in International Perspectives in Feminist Ecocriticism, eds. Greta GAard, Simon C. Estok and Serpil Oppermann. New York: Routledge, 2013. pp. 37-55: 42.

85. Rigby, Kate, "Ecocriticism," In Introducing Criticism at the $21^{\text {st }}$ Century, ed, Julian WOLFREYS. Edinburg: Edinburg University Press, 2002, pp. 151-178: 152.

86. BRAIDOtTI, Rosi, "A critical cartography of feminist post-postmodernism," Australian Feminist Studies 20: 47 (2005), pp. 1-14: 3

87. Ibid., p, 3.

88. Ibid., p. 12.

Feminismo/s 22, diciembre 2013, pp. 65-88 
- Bodily Natures: Science, Environment, and the Material Self. Bloomington, Indiana University Press, 2010.

- "Eluding Capture: The Science, Culture, and Pleasure of 'Queer Animals." In Queer Ecologies, eds, Catrinoa Mortimer-Sandilands and Bruce Erickson. Bloomington: Indiana University Press, 2010. Pp. 51-72.

- "New Materialisms, Old Humanisms, or, Following the Submersible". NORA: Nordic Journal of Feminist and Gender Research 19.4 (December 2011): pp. 280-284.

Alaimo, Stacy and Susan Hekman. "Introduction: Emerging Models of Materiality in Feminist Theory." In Material Feminisms, eds. Stacy Alaimo and Susan Hekman. Bloomington: Indiana University Press, 2008. Pp. 1-19.

BARAD, Karen. Meeting the Universe Halfway: quantum physics and the entanglement of matter and meaning. Durham, Duke University Press, 2007.

— "Nature's Queer Performativity." Qui Parle 19.2 (Spring/Summer 2011): pp. 121-158.

BARTletT, Laura and Thomas B. Byers. "Back to the Future: The Humanist Matrix." Cultural Critique 53 Posthumanism (Winter, 2003): pp. 28-46.

Bennett, Jane. Vibrant Matter: A political ecology of things. Durham: Duke University Press, 2010.

BoHM, David. Wholeness and the Implicate Order. 1980. London: Routledge, 1995.

BRAIDOTTI, Rosi. "A critical cartography of feminist post-postmodernism." Australian Feminist Studies. 20. 47 (2005): pp. 1-14.

Coole, Diana and Samantha Frost. "Introducing the New Materialisms." In New Materialisms: Ontology, Agency, and Politics, eds. Diana Coole and Samantha Frost. Durham: Duke University Press, 2010. Pp. 1-43.

Estok, Simon C. "Bridging the Great Divide: Ecocritical Theory and the Great Unwashed." ESC 31.4 (December 2005): pp. 197-209.

GAARD, Greta. "New Directions for Ecofeminism: Toward a More Feminist Ecocritcism" ISLE. 17.4 (Autumn 2010): pp. 643-665.

— "Strategies for a Cross-Cultural Ecofeminist Literary Criticism". Ecozon@. 1.1 (2010): pp. 47-52.

- "Ecofeminism Revisited: Rejecting Essentialism and Re-Placing Species in a Material Feminist Environmentalism". Feminist Formations. 23.2 (Summer 2011): pp. 26-53.

Grosz, Elizabeth. "Feminism, Materialism, and Freedom." In New Materialisms: Ontology, Agency, and Politics, eds, Diana Coole and Samantha Frost, Durham: Duke University Press, 2010. Pp. 139-157.

Guattari, Felix. The Three Ecologies. Trans. Ian Pindar and Paul Sutton. London: Continuum, 2000, Haraway, Donna, J. When Species Meet. Minneapolis: University of Minnesota Press, 2008. 
IOVINO, Serenella. "Steps to a Material Ecocriticism: The Recent Literature about the 'New Materialisms' and Its Implications for Ecocriticial Theory." Ecozon@ 3.1 (2012): pp. 134-145.

- "Toxic Epiphanies: Dioxin, Power, and Gendered Bodies in Laura Conti's Narratives." In International Perspectives in Feminist Ecocriticism, eds. Greta Gaard, Simon C. Estok and Serpil Oppermann. New York: Routledge, 2013. Pp. 37-55.

LANGSTON, Nancy. Toxic Bodies: Hormone Disruptors and the Legacy of DES. New Haven: Yale University Press, 2010.

Latour, Bruno. Pandora's Hope: Essays on the Reality of Science Studies. Cambridge, Mass.: Harvard UP, 1999.

Mortimer-SANDILANDS, Catriona and Bruce Erickson. "Introduction: A Genealogy of Queer Ecologies.” In Queer Ecologies: Sex, Nature, Politics, Desire, eds. Catrinoa Mortimer-Sandilands and Bruce Erickson. Bloomington: Indiana University Press, 2010.

Oppermann, Serpil, "Feminist Ecocriticism: A Posthumanist Direction in Ecocritical Trajectory," in International Perspectives in Feminist Ecocriticism, eds. Greta Gaard, Simon C. Estok, and Serpil Oppermann (New York: Routledge, 2013): pp. 19-36.

PiCKering, Andrew. The Mangle of Practice: Time, Agency, E Science. Chicago: University of Chicago Press, 1995.

PIPER, Arthur. "How We Became Posthuman: Ten Years On: An Interview with N. Katherine Hayles." Paragraph 33.3 (2010): pp. 318-330.

Plumwood, Val. Feminism and the Mastery of Nature. 1993. New York: Routledge, 1997.

- Environmental Culture: The ecological crisis of reason, London: Routledge, 2002.

- "Journey to the Heart of Stone." Culture, Creativity and Environment: New Environmentalist Criticism, eds. Fiona Becket and Terry Gifford. Amsterdam: Rodopi, 2007. Pp. 17-36.

— "Nature in the Active Voice." Australian Humanities Review 46 (May 2009): pp. 113-129.

POWERS, Richard. Gain. New York: Picador, 1998.

RigbY, Kate. "Ecocriticism." In Introducing Criticism at the $21^{\text {st }}$ Century, ed, Julian Wolfreys. Edinburg: Edinburg University Press, 2002. Pp. 151-178.

SOMMER, Volker and Paul L.Vasey, "Introduction. Homosexual behavior in animals: topics, hypotheses and research trajectories." In Homosexual Behaviour in Animals: An Evolutionary Perspective, eds, Sommer Volker and Paul L. Vasey. Cambridge: Cambridge University Press, 2006. Pp. 3-44.

Sturgeon, Noël. Ecofeminist Natures: Race, Gender, Feminist Theory and Political Action. New York: Routledge, 1997. 
The Posthumanities Hub. http://www.tema.liu.se/tema-g/Posthuman?l=en

TuAnA, Nancy. "Viscous Porosity: Witnessing Katrina." In Material Feminisms, eds. Stacy Alaimo and Susan Hekman. Bloomington, Indiana University Press, 2008. 188-213.

WARren, Karen, "Feminism and Ecology: Making Connections." Environmental Ethics 9.1 (1987): 13-20.

WHEElER, Wendy, "Introduction," Biosemiotics: Nature-Culture-Science-Semiosis, Living Books About Life, Open Humanities Press, JISC, 2011, n.p. http:// www.livingbooksaboutlife.org/books

- "The Biosemiotic Turn: Abduction, or the Nature of Creative Raeson in Nature and Culture." In Ecocritical Theory: New European Approaches, eds. Axel Goodbody and Kate Rigby Charlottesville: University of Virginia Press, 2011. 270-282. 